\title{
The Mediating Effect of Financial Inclusion on the Relationship between Branchless Banking Strategy and Performance of Commercial Banks in an Emerging market Context: The Case of Kenya
}

\author{
Gift Kimonge Dzombo ${ }^{1}$, James M. Kilika ${ }^{2} \&$ James Maingi $^{2}$ \\ ${ }^{1}$ Standard Chartered Bank, Kenya \\ ${ }^{2}$ Kenyatta University, Kenya \\ Correspondence: James M. Kilika, Department of Business Administration,Kenyatta University, Kenya. E-mail: \\ kilikam3@yahoo.com
}

Received: March 9, 2018

Accepted: March 26, 2018

Online Published: June 25, 2018

doi:10.5539/ijef.v10n7p161

URL: https://doi.org/10.5539/ijef.v10n7p161

\begin{abstract}
Since 1990 to date, a lot of banking innovation has taken place in order to improve commercial banks financial performance. Branchless banking which involves the use of agency banking and electronic banking channels in the distribution of banking products and services is one such innovation. This study investigated the role of financial inclusion on the relationship between branchless banking strategy and financial performance of commercial banks in Kenya. The specific objectives of the study were to analyze the effect of agency banking and electronic banking channels on the financial performance of commercial banks in Kenya. The study also aimed at determining the mediating effect of financial inclusion on the relationship between branchless banking and financial performance of commercial banks in Kenya. The study adopted a correlational research design. A survey of all the 42 licensed commercial banks in Kenya was done. Both primary and secondary data on branchless banking and financial performance of banks was obtained from the commercial banks and Central Bank of Kenya banking annual supervision reports respectively. Return on Assets (ROA) was used as the main indicator of commercial banks financial performance. The amount of investment in agency and electronic banking was used as indicators for agency and electronic banking. Data analysis was done using SPSS and STATA statistical software. Study findings indicated that when used in isolation; both agency and electronic banking had a significant negative effect on the financial performance of commercial banks. However when agency and electronic banking channels were used together as a multichannel strategy, the effect on bank's financial performance was found to be positive and significant at the 95 percent significance level. Study findings also indicate that the strength of the relationship between branchless banking strategy and financial performance of commercial banks in Kenya depends on the level of financial inclusion. The study recommends that for positive returns, commercial banks should invest in both agency and electronic banking as a multichannel strategy since these channels are complimentary to each other and calls on the government to come up with policies to foster financial inclusion within the banking industry in order for the industry to achieve maximum returns from branchless banking strategies.
\end{abstract}

Keywords: Branchless banking, financial inclusion, financial performance, multichannel strategy

\section{Introduction}

Financial services in Africa are experiencing a moment of exciting change. Many companies are taking advantage of these developments to steer emerging African economies toward a mobile-driven, cashless (or cash lite) future by introducing new products, services, and business models (Bhan, 2014). Banks globally have invested in enterprise mobile and online financial service solutions to deliver banking services and reduce the overall cost of operations (Capgemini, 2012). Capgemini (2012) further argues that though bank branches are still important in driving sales, they present the challenge of the highest operating costs to the financial institutions. The key challenge for banks is to justify the high costs of branch banking on one hand and achieving branch-driven revenue growth on the other. Also, the ever changing regulatory environment and heightened competition for retail deposits are putting pressure on banks' profitability, forcing them to reduce their overall transactions costs 
(Capgemini, 2012).

In Kenya, the financial environment has changed significantly over the last decade as a result of changes in market structure, and especially, as a result of the emerging trend towards branchless banking (Rosen, 2013). One of the main contributing factors to this transformation is the technological progress that has been taking place in Kenya in the past 10 years allowing financial institutions to provide their customers with services through alternative financial tools such as mobile banking (Rosen, 2013). According to CGAP (2008) technology can enable banks and their customers to have an interaction in a trusted way through existing local retail outlets thus branchless banking strategies have relied on the use of mobile telephone technology to enable mobile phone holders to access banking services. While consumers in United States of America are just being introduced to Apple Pay, mobile money services like MPesa and MTN Money have been flourishing in African markets (Bhan, 2014). More people have opened mobile money accounts than bank accounts in at least nine African countries, up from four in 2012 as an indication of the fact that the African continent as a whole leads the world in the adoption of financial services on the mobile platform (Bhan, 2014). Alongside this development is the opportunity availed among the economies in Africa for financial inclusion as many citizens of countries in the African continent still do not have access to formal banking and financial services.

Financial Inclusion refers to the process of creating mechanisms to expand the scope of segments of people in a society who can access and use formal financial services such as credit, savings, insurance and remittances (CGAP, 2008). Traditionally, banking and other financial services in African countries have been a preserve of segments that derive from the rich, educated, urban based residents and businesses in the formal sector. There exists empirical evidence indicating that branchless banking leads to greater access to financial services especially by the rural and unbanked population. Poor clients may be more at ease banking at their local merchant, in part because rural clients - 10 percent according to CGAP's customer research in Brazil are uneducated and need assistance in conducting and understanding their financial transactions (CGAP, 2008). Many of these customers have long-standing relationships with local merchants. In contrast, banks in many Latin American countries have a reputation of being costly, and branches and their staff are often seen as unapproachable and unfriendly (Siedek, 2008).

According to FinAccess (2006) and FinAccess (2009) household surveys, conducted by the Financial Sector Development Trust Kenya jointly with the Central Bank of Kenya, a large percentage of the Kenyan population has no access to financial products and services. The survey observed that there is a general tendency for access to services from formal and semi-formal providers (banks, SACCOs, and MFIs) to decrease as one goes from urban to rural, from high-income to low-income, and from better-educated to not educated. Although the percentage of the population that is served is similar in urban and rural districts, the mix of those services is different (FSD, 2009).

One of the main obstacles to financial inclusion is the cost involved in servicing low-value accounts and extending physical infrastructure to remote rural areas, and the cost -in money and time- incurred by customers in far-away areas to reach bank branches (KBA, 2012). For majority of Kenya's population, especially those living in rural areas, access to banking products and services has been almost absent. Ignacio (2009) observed that agency banking allows the rollout of a much more widespread distribution network without incurring the large fixed setup and operational costs of conventional branch networks. With the introduction of Mobile banking and Branchless banking services in Kenya's financial industry, inexpensive and convenient banking services continue to be provided to the large unbanked masses (Vutsengwa et al., 2013). According to a study conducted by Fin Access in 2009, financial exclusion - that is people without access to any form of financial product and services - has declined from 38.4 percent of the population in 2006 to 32.7 percent of the population in 2009. It is believed that mobile banking has made a contribution to this achievement

\subsection{Branchless Banking Strategy}

Branchless banking involves the delivery of financial services outside conventional bank branches, using retail agents or other third-party intermediaries as the principal interface with customers, and use of technologies such as card-reading point-of -sale (POS) terminals and mobile phones to transmit transaction details (CGAP, 2011). Banks are being innovative, largely due to intense competition and they are therefore at the forefront of new developments, not only in banking but also in wider financial markets (Faure, 2013). Branchless banking concept began in South America specifically in Brazil and Mexico (CGAP, 2008). Based on early experiences, branchless banking has made a significant contribution towards financial inclusion in developing countries. Most financial service providers collaborate and use partnerships with businesses that have a substantial local retail presence as a key competitive strategy (CGAP, 2008). 
In Kenya branchless banking was initially intended to improve access to financial services and products for a much larger number of Kenyan households. Due to strong competition in the banking industry, actors within the formal sector are now realizing the benefits of adopting new ways of delivering banking to the low-income and rural individuals (FSD, 2011, 2012). FSD Kenya (2009) observed that almost half (45 percent) of the adult population in Kenya is registered for M-PESA, which is twice the number of those with a bank account (23 percent). Secondly, use of mobile phone financial services more than doubled from $28 \%$ in 2009 to $62 \%$ in 2013 (FSD, 2013). According to CGAP research from 2007, at least 75 percent of Brazilians use branchless banking retail agents, compared to 43 percent who operate a bank account (Siedek, 2007).

Branchless banking also has great potential to extend the distribution of financial services to poor people who are not served by traditional bank branch networks. This is because it lowers the cost of delivery, including costs both to banks of building and maintaining a delivery channel and to customers of accessing services like travel or queuing times (CGAP, 2008). The major branchless banking channels currently in use in the Kenyan banking sector are agent banking, mobile banking, and electronic banking (online/internet banking, POS and use of ATMs).

\subsection{Financial Performance of Commercial Banks in Kenya}

Brigham and Gapenski (1997) consider that "financial performance is the net result of various policies and managerial decisions, and the financial performance rates represent the net operating result of the combined effects of liquidity, asset management and debt management". According to European Investment Bank (2013), Kenya has the most developed banking and financial system in the East African region. Its banking sector is the fourth largest in sub-Saharan Africa, behind South Africa, Nigeria and Mauritius. There are 44 commercial banks, of which 13 are foreign, and have set up 1,161 branches across the country. The Kenyan banking industry has taken advantage of the opportunities availed by branchless banking to improve financial performance. In the last few years, there has been tremendous growth in both the number and value of branchless banking transactions. According to CBK (2014) the banking agents had undertaken over 106.1 million transactions valued at Ksh 571.5 billion as at June 30, 2014.

According to the Central Bank of Kenya (2015), the overall performance remains uneven among banks despite strong growth in profitability, assets base, return on assets and return on equity. There is a significant difference gap between the top five banks and the bottom five banks across the key performance indicators. In 2014, the bottom five banks had negative return on assets and return on equity compared to the top five banks, whose ratios were strong and positive (CBK, 2015). The industry's profit before tax declined by 1.6 per cent to KSh. 69.9 billion in December 2014 from KSh. 71.0 billion in June 2014. Three banks had cumulative losses of KSh. 1.01 billion as at December 2014 compared to KSh. 0.57 billion reported in June 2014 (CBK, 2015).

A survey by FSD - Kenya indicates that agency banking had significantly increased access to banking services with 52 percent of country's population being within three kilometers of a banking agent in 2013 as compared to only 22 percent in 2009. Similar trend is being experienced in mobile money strategy around the globe (FSD, 2014). According to CGAP (2008) the strategic benefits of branchless banking are four fold. Firstly one of the strategic benefits of branchless banking is decongesting branches. Others are creating a new customer segment, expansion of geographical coverage and increasing cost efficiency. All the four benefits above have the overall effect of improving the financial performance of commercial banks. According to Capgemini (2012), branchless banking concept gives banks an opportunity to identify channels that are most important to their customers, and provide a positive experience across them. .

\subsection{Problem Statement}

Banks globally have heavily invested in enterprise mobile financial service products and services to deliver more mobile-based banking products and services and reduce the overall cost of operations (Capgemini, 2012). In response to the global trends, the Kenyan banking industry has also taken advantage of the opportunities availed by branchless banking to improve financial performance (CBK, 2014). The rapid developments in technology and changing client tastes and preferences particularly the demand for convenience and around-the-clock access to banking services is causing banking institutions to adopt technology based modes of conducting business to drive revenue through the technology based distribution systems (Frei et al., 1998).

Even though this technology is acknowledged to play a key role in the financial performance of commercial banks, the empirical literature is yet to ascertain the pay offs associated with the new technology based modes of banking (Accenture, 2008). Using the case of the banking industry in the U.S, it has been observed that large banks spend approximately $20 \%$ of their non-interest expense to invest in information technology. It is predicted that this trend is likely to continue with banks shifting from traditional to modern banking facilitated by 
technology (Accenture, 2008).

Previous studies in the banking sector seeking to explain financial performance have mainly considered bank's financial performance on the basis of the traditional revenue and cost drivers. As a result both the theoretical and empirical literatures have several weaknesses. Firstly, the theoretical literature has focused on general aspects of bank financial performance and theories of financial performance, costs and profit maximization. Secondly, the empirical literature reviewed has considered the various branchless banking strategies in isolation. This is in spite of the complementary nature of the various forms of branchless banking coupled with the banks' attempts to achieve a seamless multi-channel integration in order to maximise on the benefits of branchless banking as observed by Rosen (2013), Capgemini (2012). For example, studies done locally by Aduda and Kingoo (2012), Mwangi (2012), Ritho and Jagongo (2015) and Rosen (2008) were criticized due to their shortcomings of considering the various aspects of branchless banking in isolation.

Thirdly, all the related studies reviewed have not considered the aspect of financial inclusion which is a major goal of government policy in supporting the move towards branchless banking. Thus there is need for more research in this sector to inform financial management decisions on branchless banking using both primary and secondary data while integrating financial inclusion to explain the effect of branchless banking on financial performance of commercial banks in Kenya. Therefore the purpose of this study was to evaluate the role of financial inclusion on the relationship between branchless banking and financial performance of commercial banks in Kenya. Specifically the study aimed at analyzing the effect of agency banking on the financial performance of commercial banks in Kenya. Secondly, the study aimed at analyzing the effect of electronic banking on the financial performance of commercial banks in Kenya. Lastly, the study also aimed at determining the mediating effect of financial inclusion on the relationship between branchless banking and financial performance of commercial banks in Kenya.

\section{Literature Review}

\subsection{Theoretical Review}

The concept of branchless banking ushers a phenomenon whose empirical investigation requires an understanding of the theoretical grounding of the phenomenon. Thus Various theories are applicable to this study in explaining the practice of branchless banking and the phenomenon it brings about not only in the industry but also in the economy. The paper considered several theories that were considered suitable in explaining and understanding branchless banking as a phenomenon in financial management.

Firstly, the financial intermediation theory and by extension contemporary banking theory emphasize the role of commercial banks as financial intermediaries. The two theories suggest that due to information asymmetry between borrowers and lenders, commercial banks and other financial intermediaries are necessary in order to efficiently allocate capital resources in the economy. Financial intermediation theory was postulated by Douglas (1984) and argues that information asymmetry arises in the financial system and markets between borrowers and lenders because borrowers generally know more about their investment projects than lenders do (Claus \& Grimes, 2003). According to the theory, financial intermediaries act as middlemen hence leading to net cost savings. The model provides strong predictions about the contracts used by financial intermediaries and thus provides a setting to analyze important issues in banking policy.

According to Brigham and Gapenski (1993) financial intermediaries do not only transfer money and securities between firms and savers- they also create new financial products. Brigham and Gapenski (1997) further argue that since the financial intermediaries are generally huge, they create economies of scale in analyzing the credit worthiness of potential borrowers, in processing and collection of loan facilities and in pooling of risk and thus helping individual savers diversify. Contemporary banking theory was postulated by Bhattacharya and Thakor (1993). The theory was an extension of the financial intermediation theory. Contemporary banking theory suggests that commercial banks and other financial intermediaries are necessary in order to efficiently allocate capital resources in the economy. The theory suggests that financial intermediaries benefit the economy as they help to reduce the transaction costs for services ranging from brokerage to attribute transformation.

The other three theories used in the study were the bank-led theory, non-bank led theory and bank focused theory. These theories mainly seek to explain how branchless banking is conducted, explain the branchless banking risks and opportunities and hence contribute to the independent variables of the study. In the bank-led theory of branchless banking, a licensed financial institution distributes financial services and products through a retail agent. According to CGAP (2006), the bank develops financial products and services and distributes them through retail agents who handle all or most of the customer interactions. The principal bank is the eventual provider of financial services and it is the institution in which customer's accounts are maintained. Retail agents 
have face-to-face interactions with customers and perform cash in/cash-out functions, the same way a branch-based teller would take deposits and process cash withdrawals (Owens, 2006).

Under the nonbank led theory, customers do not deal with a bank or maintain a bank account. Instead, they deal with a nonbank firm either a mobile network operator or prepaid card issuer and retail agents serve as the point of customer contact. In this model customers exchange their cash for e-money stored in a virtual e-money account on the nonbank's server, which is not connected to a bank account in the individual's name (Kumar et al., 2006). This model is more risky as the regulatory environment in which these nonbanks outlets operate might not give much importance to issues related to customer due diligence which may lead to significant Anti-Money Laundering and Counter-Terrorism Financing (AML/CFT) risks. Under the bank-focused theory, a conventional bank uses non-traditional inexpensive delivery channels to provide banking services to its existing customers. Examples range from use of automatic teller machines (ATMs) to internet banking or mobile banking to provide certain limited banking services to bank customers. Use of ATMs is complementary in nature and may be seen as a modest extension of conventional branch-based banking. This offers advantages such as more control and branding visibility to the concerned financial institutions. However there are concerns with the experience, protection of identity and transactions, consistency and accessibility of service and extent of personalization allowed.

\subsection{Conceptual and Empirical Review}

In this section the study briefly reviews the constructs that underpin the study and some empirical studies that have been done in the Kenyan sector.

\subsubsection{Bank Financial Performance}

Brigham and Gapenski (1997) consider that "profitability is the net result of various policies and managerial decisions, and the profitability rates represent the net operating result of the combined effects of liquidity, asset management and debt management". There has been alot of debate as to which profitability ratio between ROA and ROE is the best measure of financial performance. Hagel et al. (2010) observed that most Wall Street analysts and investors tend to focus on return on equity as their primary measure of company performance. Many executives focus heavily on this metric as well, recognizing that it is the one that seems to get the most attention from the investor community (Hagel et al., 2010). Hagel et al. (2010) further argues that ROE can be used to divert attention from business fundamentals and lead to nasty surprises. Companies can resort to financial strategies to artificially maintain a healthy ROE for a while and hide deteriorating performance in business fundamentals. They therefore conclude that ROA is a better metric of financial performance as it explicitly takes into account all the assets used to support business activities. Using ROA as a key performance metric quickly focuses management attention on the assets required to run the business.

A number of studies conducted demonstrate how this understanding has been applied to conceptualize several constructs in relation to performance of the financial sector in Kenya. According to Ongore and Kusa (2012), the financial performance of banks has significant implications for economic growth of the entire country. Good financial performance rewards the shareholders for their investment. This in turn encourages further investment and brings about economic development. On the other hand, poor banking performance can lead to banking failure crisis which has negative repercussions on the economic growth. Studies have revealed that commercial banks in Sub-Saharan Africa (SSA) are more profitable than the rest of the world with an average Return on Assets (ROA) of 2 percent over the last 10 years. This rate of return is significantly higher than bank returns in other parts of the world (Flamini et al., 2009). In their study, Ongore and Kusa (2012) further examined the determinants of financial performance of commercial banks in Kenya. They used the CAMEL approach to check up the financial health of commercial banks in Kenya. They found out that capital adequacy, asset quality and management efficiency significantly affect the performance of commercial banks in Kenya. They also observed that financial performance of commercial banks in Kenya is determined mainly by board and management decisions while macroeconomic factors had inconsequential contribution. The study failed to capture any form of branchless banking but rather concentrated on economic factors and management skills as the key determinants of commercial banks financial performance

Kongiri (2012) studied the effects of CAMEL variables on commercial bank efficiency as measured by the efficiency ratio of Kenyan commercial banks. The study adopted a panel data design and descriptive research design to meet its objectives. Annual financial statements of 37 Kenyan commercial banks from financial years 2007 to 2011 were obtained from the CBK. The data made up of a sample of 185 study units was analyzed using multiple linear regression method. Findings led to the conclusion that Capital Adequacy, Earnings and Liquidity ratio have a negative relationship to efficiency ratio while Management quality and Asset Quality have a positive 
relationship.

Odunga et al. (2013) studied the effect of bank specific performance indicators including credit risk capital adequacy on the operating efficiency of commercial banks in Kenya.The study adopted an explanatory research design and analysed the panel data using Fixed Effects Regression. The results of the study indicated that the previous year operational efficiency and risk based capital ratio positively and significantly affected the bank's operating efficiency in the current year. This implies that the history of a firm's performance will absolutely influence how a firm moves forward in an effort to rationalize its operational strategies. Banks should seek mechanisms to improve their risk based capital ratio in order to improve operating efficiency and remain competitive in the market.

Kamau (2011) conducted a study to investigate the intermediation efficiency and productivity in the banking sector in the post liberalization period in Kenya. The study was motivated by the fact that although the banking sector constitutes a large part of the financial system in Kenya, little information is available about its intermediation efficiency and productivity position. The study adopted a non-parametric Data Envelopment Analysis (DEA) to analyze intermediation efficiency in the banking sector and Malmquist Productivity Index (MPI) to measure the productivity gains of banks in Kenya. She observed that though the banks were not fully well-organized in all respects, they performed fairly well during the period under study. She also observed that banks still have the rationale and scope to improve performance by improving their technology, skills and enlarging their operational scale so as to be fully efficient. The study recommended policies encouraging competition, products diversification to advance loans, risks minimization through increased capital regulation and privatization of some banks. The shortcoming of the study is that it used DEA (Data Envelopment Analysis) which benchmarks against the best performers in the industry and may not be the most suitable model to analyze intermediation efficiency.

Veniard et al. (2010) used confidential cost and revenue estimations provided by three service providers in Africa, one in Asia, and three in Latin America. They found that agent banking does help improve the economics for these institutions compared with branches, especially for high-transaction, low-balance accounts that is a common feature among poor financial services users. Mols et al. (1999) in their paper titled "Distribution channel strategies in Danish retail banking", observed that in the Danish banking sector, the intensified competition has recently resulted in a number of banks launching non-bank financial services and products through their branches as well as insurance companies and other financial companies opening banks. The battle for the customers is however also fought through new electronic distribution channels. Their study focused on telephone banking, PC banking and Internet banking as the only convenient distribution strategies in the modern times. This study left out agent banking which has emerged as another convenient modern distribution channel.

\subsubsection{Branchless Banking and Financial Inclusion}

Rosen (2013) examined whether the use of mobile banking and agent banking can live up to the promise of lifting the welfare of low-income earners in Kenya. Potential welfare gains were identified and these gains were later explored in a household survey. The survey examined the effects from these non-conventional channels on low-income individuals based on their ability to save, to invest and to consume as well as the effects on their overall wellbeing in terms of food security and health. Findings from this study suggest that mobile banking and agent banking have facilitated the delivery of financial services to the population in Kenya that was previously excluded and the result is an economic lift in overall wellbeing.

According to FinAccess 2013 survey report, agent banking was cited as a very popular channel despite being relatively new. Of the respondents interviewed, $53.2 \%$ of the respondents admitted that they were aware of agent banking. $12.2 \%$ of the respondents admitted having used the services of a banking agent in the past (CBK, FSD, 2013). This proves the fact that agent banking is currently a very popular branchless banking channel. Mobile banking ownership has also been on a rising trend in both rural and urban areas since 2006. According to FinAccess survey 2013 report conducted by FSD and CBK, mobile banking ownership has increased to 83.8\% and $61.5 \%$ in 2013 in urban and rural areas respectively from 53\% and $19.2 \%$ respectively in 2006. In line with this growth in the ownership use of mobile money for domestic remittances increased to $91 \%$ and $60 \%$ in rural and urban areas respectively. This increase has been phenomenal considering the fact that in 2006 the idea of domestic remittances using mobile money was non-existent (FSD, 2013).

Fin Access survey 2013 report further cited mobile banking agents as the nearest financial providers by $76.4 \%$ and $75.5 \%$ of the respondents in rural and urban areas respectively. $85.8 \%$ of the adults in urban areas can walk to the nearest mobile money agent and $60.4 \%$ to the nearest bank retail agent (CBK, FSD, 2013). These figures emphasize the growing importance of the branchless banking channels (specifically mobile banking and agency 
banking) due to their accessibility and convenience to the masses. The impact of branchless banking strategies on financial inclusion indicates that branchless banking channels can work as a bridge between the institutions and the excluded, given that the right kind of financial tools are provided in order for opportunities to be created through financial inclusion.

Ndungu and Njeru (2014) conducted a study to assess some of the factors that contribute to the adoption of agency banking in Kajiado Sub County of Kenya. Three independent variables were considered namely customer service, convenience and quality of agents. Some of the results indicated that availability of the system contributes to reliability of the service which increases the adoption and use of agency banking. The findings further indicated that complaints resolution time does not affect the adoption and use of agency banking and that Agency banking is delivering convenience in form of extended hours of banking and by bringing the banking service closer to the customers leading to increased adoption and use of agency banking.

\subsection{Conceptual Framework and Hypotheses}

Based on the literature reviewed, the paper proposed a conceptual framework comprising three types of variables as presented in Figure 1.

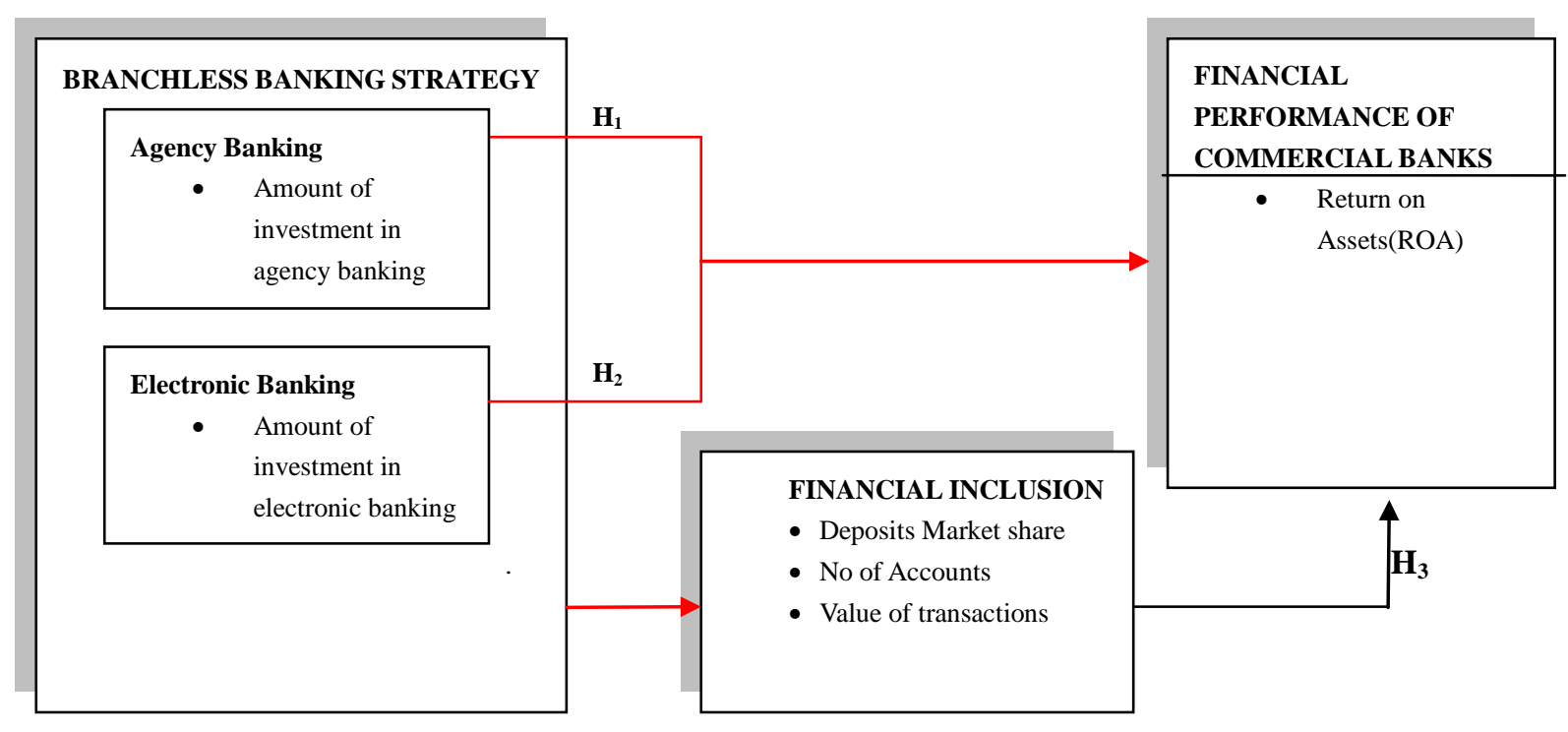

Figure 1. Conceptual framework

The independent variable in the conceptual framework for this study is made up of various Branchless banking distribution channels like agency banking and electronic banking (Mobile banking, online/internet banking, ATM banking and POS channels). It is assumed that the amount invested on agency banking may have an effect on the commercial bank's financial performance (dependent variable) but this effect is mediated by level of financial inclusion.

The presumed interrelationships between the study variables is decomposed into 3 sub models. The first proposed model depicts the direct relationship between agency banking (independent variable) and financial performance of commercial banks (dependent variable). The main indicator for agency banking is the amount of investment in agency banking. The main indicator of commercial bank's financial performance is Return on Assets (ROA) .However, according to Hagel et al. (2010), ROA is a better measure of financial performance than ROE as it explicitly takes into account all the assets used to support business activities and using ROA as a key performance metric quickly focuses management attention on all the assets required to run the business. In this study ROA was used as a measure of performance since it takes into account all assets used to generate income for the business. The second sub model shows the second direct relationship between electronic banking (independent variable) and financial performance of commercial banks (dependent variable). Just like in the first sub model the main indicator for electronic banking is the amount of investment in electronic banking and the indicator for commercial bank's financial performance is Return on Assets (ROA).

The third sub model depicts the mediating effect of financial inclusion on the financial performance of 
commercial banks. Deposits market share, number of accounts and value of transactions were used as indicators for financial inclusion. Through the mediating effect of financial inclusion, the principal banks are able to reach new customer segments and previously unbanked population hence increasing their deposits market share and consequently improve their financial performance.

\subsection{Research Hypotheses}

Based on the conceptual framework and accompanying explanation, the study hypothesized that: Hypothesis One:

$H_{l}$ : Agency banking has a significant effect on the financial performance of the Kenyan commercial banks. Hypothesis Two:

H2: Electronic banking has a significant effect on the financial performance of commercial banks in Kenya. Hypothesis Three:

H3: Financial inclusion has a significant mediating influence on the relationship between branchless banking and financial performance of commercial banks in Kenya.

\section{Research Methodology}

\subsection{Research Design}

This study adopted a correlational research design. This is because the study involved tests to determine the relationship between variables (Creswell, 2008). The study tested the effect of the independent variable (branchless banking) on the dependent variable (financial performance of commercial banks) and also the effect of the mediating variable (financial inclusion).

\subsection{Population and Research Data}

The study adopted a census approach to study all commercial banks in Kenya. Study was conducted on all the 42 licensed commercial banks in Kenya as at 2014. The adoption of branchless banking was not uniform across the industry, and not all the 42 banks had adopted branchless banking by end of financial year 2014. The study required secondary data that was obtained in quantitative form. The data was to cover the period 2009-2014. A Questionnaire was designed with specific questions on data to be provided from each bank on the variables of the study. The questionnaires were delivered to the head offices of all the 42 commercial banks in Kenya hence a total of 42 questionnaires were delivered- one questionnaire for each commercial bank. The unit of analysis was the individual banks and this information was sought from the bank's head of finance or the IT departments because of the strategic nature of the data required.

\subsection{Data Analysis}

Both the primary and secondary data collected was merged into one spread sheet to obtain an unbalanced panel. Data was compiled and organized using Microsoft Excel and analyzed using SPSS (for descriptive analysis) and STATA statistical software (for inferential analysis). Data analysis procedure began with computation and tabulation of descriptive statistics. To arrive at the appropriate model, between fixed effects model and random effects model, hausman specification test was used. Other diagnostics tests to test for stationarity/unit root (fisher type unit root test) and serial correlation were also conducted. Panel regression model was used to analyze the data in testing the hypotheses. Two forms of panel regression test were performed in order to test the direct and mediating effects. The Regression model used for the direct effect was of the form:

$$
R O A_{i t}=\alpha+\beta_{1} A G B O_{i t}+\beta_{2} E L B O_{i t}+u_{i t}
$$

The mediating effect regression model took the form:

$$
R O A_{i t}=\alpha+\beta_{1} A G B O_{i t}+\beta_{2} E L B O_{i t}+M+u_{i t}
$$

Where

$$
M=\alpha+\beta_{3} \mathrm{FI}+u_{i t}
$$

Source; Baltagi (2010).

Where;

$\alpha=$ intercept/constant term

$A G B O=$ Agent banking

$E L B O=$ this refers to electronic banking which comprises of Mobile banking, Automatic Teller Machines, 
online banking and point of sale terminals.

Betas $(\beta)$ were the coefficients of the models to be estimated

$u_{\text {it }}=$ the error term. It includes other factors outside the model that may also have effect on bank's financial performance.

$F I=$ Represents financial inclusion which was a composite value of the banks deposit market share, number of accounts opened through branchless banking and value of transactions conducted through branchless banking. A geometric mean procedure was used to compute the composite value from the 3 sub variables. One of the advantages of geometric mean procedure is that it helps to reduce the effect of outliers and also normalize the research data (Vandesompele et al., 2002; Wu \& Ye, 2009). The formula for geometric mean is expressed as: $\mu=$ (X1.X2.X3 ........Xn) $1 / \mathrm{n}$,

Where;

$\mathrm{X} 1, \mathrm{X} 2, \mathrm{X} 3, \ldots \ldots . \mathrm{Xn}$ are the scores for the respective sub variables up to nth sub-variable (Vandesompele et al., 2002; Wu \& Ye, 2009).

\section{Results and Disussions}

\subsection{Diagnostic Tests Results}

Table 1. Diagnostic tests results

\begin{tabular}{|c|c|c|c|}
\hline $\begin{array}{l}\text { Type of } \\
\text { diagnostic test }\end{array}$ & Statistical Technique & $\begin{array}{l}\text { Interpretation } \\
\text { /Decision criteria }\end{array}$ & Results and Decision \\
\hline $\begin{array}{l}\text { Fixed and } \\
\text { random } \\
\text { modelling } \\
\text { assumption }\end{array}$ & $\begin{array}{l}\text { Hausman test } \\
\text { Denoted as } H \text {, used to } \\
\text { determine whether to run the } \\
\text { fixed effects or the random } \\
\text { effects model. } \\
\text { Has a chi-square distribution } \\
\text { with degrees of freedom } \\
\text { equal to the number of } \\
\text { regressors in the model }\end{array}$ & $\begin{array}{l}\text { At } 5 \% \text { conventional } \\
\text { significance level a P- value } \\
\text { less than } 5 \% \text { implies that the } \\
\text { two models are statistically } \\
\text { different hence the null } \\
\text { hypothesis can be rejected. }\end{array}$ & $\begin{array}{l}\text { Chi } 2 \text { statistics were greater than } 5 \% \text {. Null } \\
\text { Hypothesis was rejected. Fixed effects model } \\
\text { was used. } \\
\text { Mediated relationship: Chi } 2 \text { statistics were } \\
\text { greater than 5\%. Random effects model was used }\end{array}$ \\
\hline $\begin{array}{l}\text { Unit Root Test/ } \\
\text { Stationary Tests. }\end{array}$ & Fisher - type unit root test & $\begin{array}{l}\text { Null hypothesis is that each } \\
\text { series in the panel contains a } \\
\text { unit root while the alternative } \\
\text { allows for some (but not all) of } \\
\text { the individual series to have } \\
\text { unit roots. }\end{array}$ & $\begin{array}{l}\text { The } \mathrm{p}-\text { values for the statistics were all } 0 \text { percent. } \\
\text { Since the } \mathrm{p} \text { - values are less than } 5 \text { percent at } 5 \\
\text { percent significance level }(0.05) \text { then the null } \\
\text { hypothesis was rejected and the alternative } \\
\text { hypothesis is accepted implying that there are no } \\
\text { unit roots in the panels }\end{array}$ \\
\hline $\begin{array}{l}\text { Serial } \\
\text { Correlation/Auto } \\
\text { Correlation }\end{array}$ & $\begin{array}{l}\text { Breusch Godfrey (BG) test. } \\
\text { This test is used to test auto } \\
\text { correlation of any order. } \\
\text { Ho: } \rho 1=\rho 2=\rho 3=\ldots \rho q=0\end{array}$ & $\begin{array}{l}\text { Compute the } \mathrm{F} \text { test for the joint } \\
\text { significance of the residuals } \\
\text { If } \wedge^{\wedge}>\mathrm{F} \text { critical reject null of } \\
\text { no } \mathrm{q} \text { order autocorrelation }\end{array}$ & $\begin{array}{l}\text { The probabilities of all the respective LR chi2 } \\
\text { statistics were less than } 0.05 \text { ( } 5 \text { percent } \\
\text { significance level). Panels were serially } \\
\text { correlated. To correct this the models were } \\
\text { estimated using the generalised least squares } \\
\text { method and robust standard errors }\end{array}$ \\
\hline $\begin{array}{l}\text { Multicollinearity } \\
\text { tests }\end{array}$ & $\begin{array}{l}\text { Spearman's } \\
\text { matrix }\end{array}$ & $\begin{array}{l}\text { If correlation coefficient } \\
\text { between two variables is below } \\
0.7 \text {, it is ok to include in the } \\
\text { model. Any two variables with } \\
\text { a correlation coefficient of } 0.7 \\
\text { or more, remove from the } \\
\text { model. }\end{array}$ & $\begin{array}{l}\text { Most of the coefficients of individual variables } \\
\text { were below } 0.7 \text {. The only strong correlation was } \\
\text { between ROA and ROE ( } 0.869) \text { and also the } \\
\text { correlation between agency banking value of } \\
\text { transactions and electronic banking value of } \\
\text { transactions with a correlation of } 0.8030 \text {. These } \\
\text { were dropped from the model to ensure that the } \\
\text { model doesn't generate biased estimates }\end{array}$ \\
\hline
\end{tabular}

\subsection{Results of Descriptive Analysis}

\subsubsection{Agency Banking}

From the descriptive analysis, a key observation is that agency banking investment has been on steady rise over the years 2010-2014. Another key observation is that most of the banks adopted agency banking between year 
2011 and 2012. Only 8 out of 32 banks (25 percent) had adopted agency banking by the end of financial year 2014. Below is a chart showing the trend of agency banking investment in the industry in the period under review.

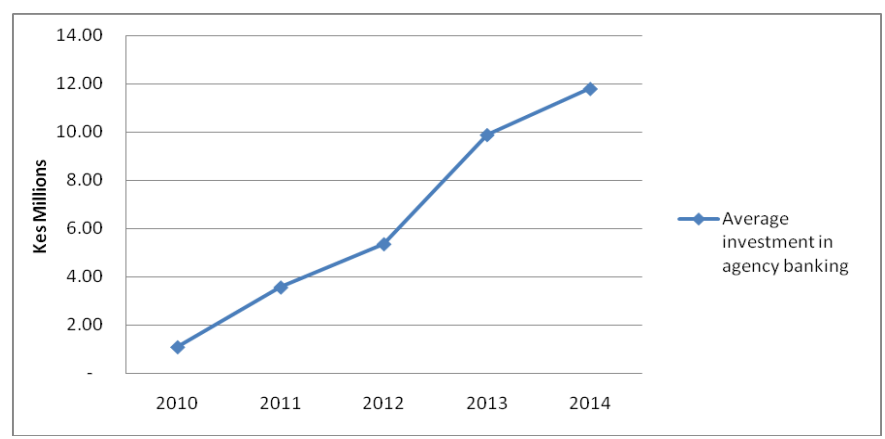

Figure 2. Trend analysis of average investment in agency banking at bank level

\subsubsection{Electronic Banking}

Descriptive analysis of electronic banking indicates that electronic banking investment has been on the increase over the period 2010 to 2014 with the highest rate of increase in the period 2011 to 2012.97 percent of the banks had adopted at least one electronic banking channel by financial year 2014. Majority of the banks (34 percent) had operated electronic banking channels for more than 3 years.

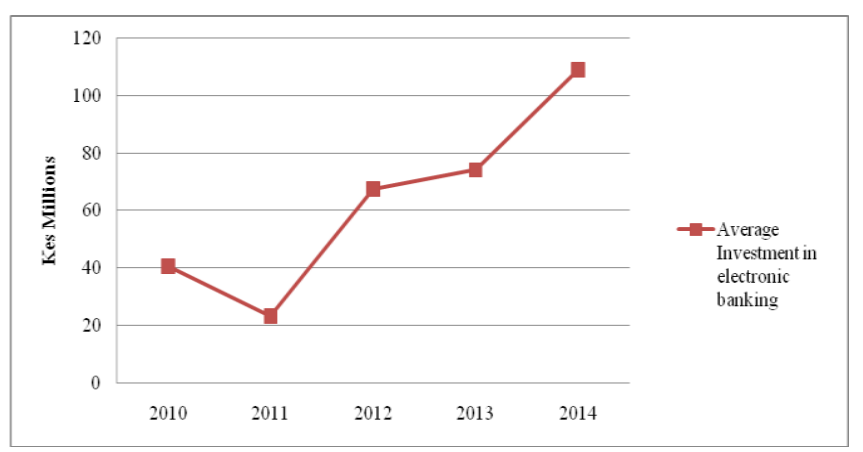

Figure 3. Trend analysis of electronic banking investment

\subsubsection{Financial Inclusion}

Analysis of the variable financial inclusion indicates that the adoption rate of electronic banking in the banking industry was higher than agency banking. Both agency and electronic banking transactions had wide variability/fluctuations. Both the number of accounts and agency banking transactions had been on an upward trajectory over the period under study-evidence of increasing financial inclusion

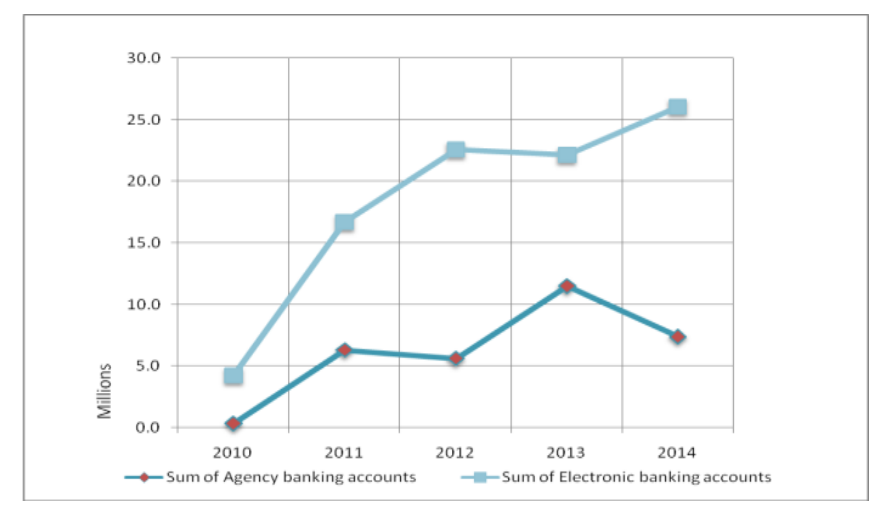

Figure 4. Trend analysis of agency and electronic banking accounts 


\subsubsection{Financial Performance of Commercial Banks}

A glaring observation on the descriptive analysis of the variable financial performance of commercial banks is that despite banks posting increased net profits year on year, critical analysis reveals mixed results on the average Return on Assets (ROA) and average Returns on Equity for the period. Average Return on Assets (ROA) for the industry has remained relatively flat over the years indicating that the increase in earnings is followed by almost the same proportion of increase in assets investment.ROE has been on a declining trend in the period under review. The chart below provides a trend analysis of ROA and ROE in the banking industry for the study period.

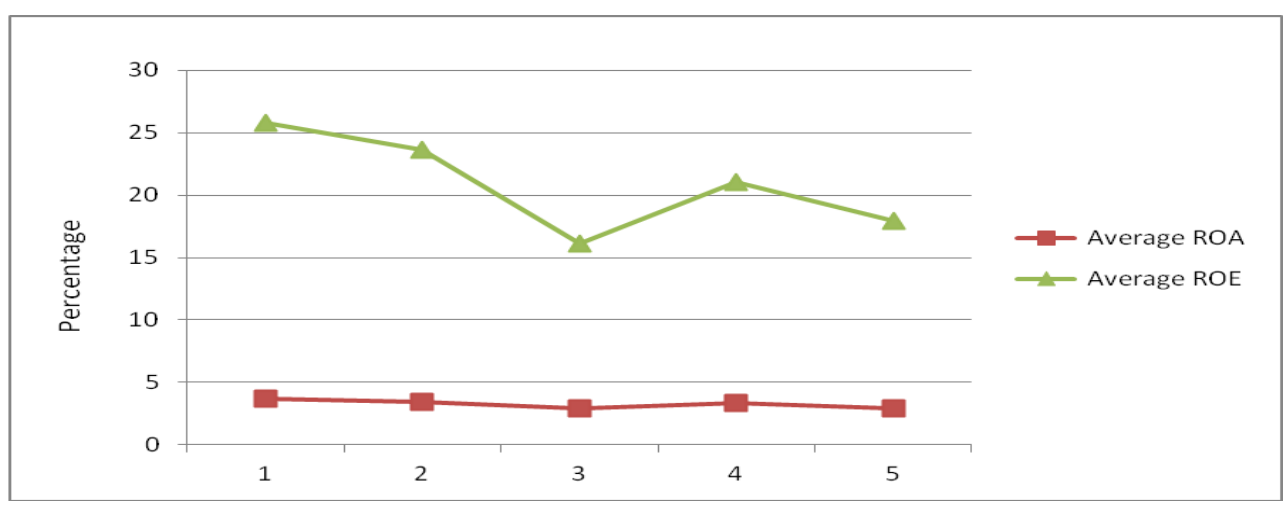

Figure 5. Trend analysis of ROA and ROE in the banking industry for the study period

\subsection{Hypotheses Tests Results}

\subsubsection{Results for Hypothesis One and Two}

Hypothesis one and two were tested using one-step simple regression analysis. Hypothesis three involved a four step approach in which several regression analyses were conducted and significance of the coefficients is examined at each step. For hypotheses testing, the definition of the models used in the diagnostic tests was used. Amount of investment in agency and electronic banking was used as indicators for agency and electronic banking respectively. Bank's deposits market share, number of branchless banking accounts and value of branchless banking accounts were used as indicators of financial inclusion. Table 2 summarizes the hypothesis tests results.

Table 2. Summary of the hypothesis tests results

\begin{tabular}{cccccc}
\hline & & \multicolumn{4}{c}{ ROA } \\
\cline { 3 - 6 } Model & Coef. & Robust Std. Err. & $\mathrm{z}$ - stat & $\mathrm{P}>|\mathrm{t}|$ & Conclusion \\
\hline Agency Banking & -0.0010 & 0.00011 & -8.81 & 0.000 & $\mathrm{H}_{1}$ Supported \\
Electronic Banking & -0.0010 & 0.00008 & -12.64 & 0.000 & $\mathrm{H}_{2}$ Supported \\
\hline
\end{tabular}

Source: Survey data, 2016.

The results of the test of hypothesis one and two show that both hypotheses are supported. The conclusion of the study is that when used in isolation, both agency and electronic banking had a significant negative effect on financial performance. Thus, each of the components of the Branchless Banking strategy negatively affect performance of commercial banks in Kenya

\subsubsection{Results for Hypothesis Three}

Hypothesis three sought to analyze the mediating influence of financial inclusion on the relationship between branchless banking and financial performance of commercial banks in Kenya. The hypothesis was that financial inclusion has a mediating effect on the relationship between branchless banking and financial performance of commercial banks in Kenya. The main indicators for mediating variable in this model were deposits market share, agency and electronic banking accounts and value of transactions. To obtain a single indicator for financial inclusion, a composite value of the 3 sub variables was obtained through a geometrical mean procedure (Vandesompele et al., 2002; Wu \& Ye, 2009). A composite index for branchless banking was also obtained by 
computing a geometric mean of the two sub variables agency banking and electronic banking. To test for the mediating effect, the model proposed by Baron and Kenny (1986) was used. This involved a three step approach in which several regression analyses were conducted and significance of the coefficients examined at each step. The analysis was presented by each of the three steps for ROA.

Table 3. Summary of regression results for hypothesis three

\begin{tabular}{lccccc}
\hline Parameter & $\begin{array}{c}\text { Indicator for } \\
\text { dependent } \\
\text { variable }\end{array}$ & $\begin{array}{c}\text { Model 1 } \\
\text { Independent } \\
\text { Variable }\end{array}$ & $\begin{array}{c}\text { Model 2 } \\
\text { Mediator } \\
\text { \& Dependent }\end{array}$ & $\begin{array}{c}\text { Model 3 } \\
\text { Independent, Mediator and } \\
\text { Dependent }\end{array}$ & Change \\
\hline $\begin{array}{l}\beta \text { Branchless } \\
\text { Banking }\end{array}$ & ROA & $0.00004^{* *}$ & & $0.00003^{* *}$ & -0.0000 \\
$\begin{array}{l}\beta \text { Financial } \\
\text { inclusion }\end{array}$ & ROA & & $0.00017^{* *}$ & $0.00016^{* *}$ & 1 \\
$\beta$ Constant & ROA & $3.54^{* * *}$ & $3.450^{* *}$ & $3.4415^{* *}$ & -0.0000 \\
exist and is significant & -0.0985 \\
\hline
\end{tabular}

Note. $* *$ significant at $\mathrm{p}<0.05 ; * * *$ not significant at $\mathrm{p}>0.05$.

Source; Survey data, 2016.

Table 3 above summarises the differences in the regression results of branchless banking on financial performance before and after introduction of the mediating variable. From the table above, the differences in the regression results before and after introduction of mediating variable clearly suggest that the mediating variable financial inclusion has played an important role in the relationship between branchless banking and financial performance of commercial banks in Kenya. The analysis of the coefficients for branchless banking and ROA shows evidence of partial mediation and the effect is significant at 5 percent significance level. The above set of results therefore indicates that financial inclusion partially mediates the relationship between branchless banking and financial performance of commercial banks in Kenya. This implies that hypothesis three which stated that financial inclusion has a mediating effect on the relationship between branchless banking and financial performance of commercial banks in Kenya was supported. The conclusion was that the strength of the effect of branchless banking on performance of commercial banks in Kenya depends on the level of financial inclusion

\section{Discussions and Implications for Theory}

The reported results on the test of the hypotheses raise a number of implications for theory and practice. The first implication arises from the negative effect observed from the test of hypotheses one and two. The negative effect could be explained by the fact that the actual investment in agency banking and electronic banking in quantitative terms is an expense and as such it reduces the operating profit which eventually leads to the decline in ROA through reduced net profits. According to the theory of the firm, the objective of the management of any organisation is profit maximization. And for sustainable financial performance, fixed costs have to be managed. Banks are therefore progressively moving towards a business model where costs are relatively variable and are incurred only where there are sales involved. To achieve this banks have to make significant initial investment in IT whose benefits would not necessarily accrue in the short run. The descriptive analysis results on the variable had indicated that the average investment in agency banking has been increasing exponentially year on year at bank level as banks seek to strengthen their IT infrastructure to maximise on the opportunities and at the same time minimise the risks associated with agency banking.

Another explanation to the negative effect arises from the fact that since most banks are still in the investment phase of branchless banking, there is a possibility that the sales revenue being generated from this channel at bank's level are still below the breakeven point. The breakeven point is the sales volume required so that total revenues are equal to total costs (Horne \& Wachowicz, 2001). At the banks level, there is a possibility that most banks are not generating sufficient volumes of agency banking transactions and the resultant revenues generated are still less than the investment made on agency banking. The amounts invested in branchless banking infrastructure could be also be expensed at the financial years when these costs are incurred hence the negative effect on financial performance.

Secondly, the combination of the two strategies while testing for hypothesis three raises important lessons. The regression results indicated that when both agency and electronic banking were used together as a multichannel strategy, there was a significant positive effect. This therefore implies that the two channels are complementary to each other and banks would benefit more from their branchless banking investment if they used a multichannel strategy as opposed to adoption of a single channel strategy. Combination of agency banking and 
electronic banking investment creates synergy which could be explained using the systems theory concept of synergy where the whole is greater than the sum of its constituent parts. This therefore implies that the two channels are complementary to each other and banks would benefit more from their branchless banking investment if they used a multichannel strategy as opposed to adoption of a single channel strategy.

Thirdly, the results on the test of the mediating effect of financial inclusion offers useful insights on the role of financial inclusion. First, using the descriptive results presented on the variable of financial inclusion, it was observed that both the number of accounts and agency banking transactions conducted during the period had been on an upward trajectory year on year implying that the members of the population who were previously excluded from the banking system are progressively being accommodated within the banking industry. With the introduction of branchless banking services in Kenya's financial systems, inexpensive and convenient banking services continue to be provided to the large unbanked masses (Vutsengwa et al., 2013). Secondly, according to a study conducted by Fin Access in 2009, financial exclusion which refers to people without access to any form of financial services has declined from 38.4 percent in 2006 to 32.7 per cent of the population in 2009. This increase in the population that has been accommodated by the banking system has been the major driver to the relationship between branchless banking and financial performance of commercial banks in Kenya. The impact of branchless banking on financial inclusion indicates that branchless banking channels can work as a bridge between the institutions and the excluded (CBK, FSD, 2013).

Finally, while in the past financial inclusion has been argued to have positive contribution to the economy through the banking industry, the argument has not been accompanied by empirical evidence to explain how financial inclusion contributes towards their development. Whereas in the test of direct relationship the effect of agency and electronic banking on financial performance showed a negative effect, when the mediating variable financial inclusion was introduced the strength of the relationship marginally declines but remains positive. Thus the findings point to the direction that the strength of the relationship between branchless banking and financial performance of commercial banks in Kenya depends on financial inclusion.

The findings of the current study make several contributions to financial management in general and commercial banking management in particular. Firstly, the empirical findings of this research have clearly explained the effect of agency and electronic banking on commercial banks financial performance. Secondly, the study observed that when both agency and electronic banking were used together as a multichannel strategy, the effect on financial performance is significantly positive, on the other hand when they were used in isolation; the effect on the financial performance of commercial banks was negative. The study therefore complements the traditional financial management theories by incorporating the systems concept of synergy in explaining the effect of branchless banking and financial performance of commercial banks. In this study, the traditional financial management theories have been complimented by the theories in management underpinning strategic decisions in organizations.

\section{Conclusions and Recommendations}

The study aimed at evaluating the effect of branchless banking on the financial performance of commercial banks in Kenya. From the research findings and the explanations offered, the study makes four major conclusions. Firstly, the study concludes that even though agency banking and electronic banking when used in isolation as branchless banking strategies negatively affect performance of commercial banks in Kenya, yet when combined as a multichannel strategy, their effect on performance of commercial banks in Kenya is positive. Secondly, the strength of the effect of branchless banking on performance of commercial banks depends on the level of financial inclusion generated by the banks from the application of the branchless banking strategies.

From the study findings and conclusions, the study makes several recommendations. Firstly, commercial banks should adopt agency and electronic banking as a multichannel strategy as opposed to single channel strategy for positive returns on financial performance. This is because there is synergy when these two channels are adopted together as the two channels are complementary to each other. Secondly, study findings point to the direction that the strength of the relationship between branchless banking and financial performance of commercial banks in Kenya depends on financial inclusion. Therefore the government should come up with policies to foster financial inclusion within the banking industry in order for the industry to achieve maximum returns from branchless banking.

\subsection{Areas for further Research}

This study only focused on licensed commercial banks. A similar study could be conducted on other non banking financial institutions like Microfinance institutions and SACCOs as these also heavily utilize some of the branchless banking channels in their distribution network. Secondly, a study could be done to determine the 
effect of electronic banking on the cost efficiency of commercial banks in Kenya. Thirdly, for the purpose of this study, electronic banking combined mobile banking, internet banking, ATMs and POS channels as one independent variable. A study could be done to analyze the effect of the individual components of electronic banking as separate variables to determine their individual and specific effects on commercial banks financial performance. Lastly, a study could be done to analyze the effect of bank innovations on customer experience and loyalty.

\section{References}

Accenture. (2008). A Strategic Approach to Cost Reduction in Banking. Achieving High Performance in Uncertain Times. Retrieved on $11^{\text {th }}$ Aug 2014 from http://www.accenture.com

Aduda, J., \& Kingoo, N. (2012). The Relationship between Electronic Banking and Financial Performance among Commercial Banks in Kenya. Journal of Finance and Investment Analysis, 1(3), 99-118.

Baltagi, B. H. (2008). Econometric Analysis of Panel Data. John Wiley \& Sons, Ltd., England.

Baltagi, B. H. (2011). Econometrics (5th ed.). Berlin: Springer. https://doi.org/10.1007/978-3-642-20059-5

Baron, R. M., \& Kenny, D. A. (1986). The moderator-mediator variable distinction in social psychological research: Conceptual, strategic, and statistical considerations. Journal of Personality and Social Psychology, 51(6), 1173-1182. https://doi.org/10.1037/0022-3514.51.6.1173

Bhan, N. (2014). Mobile Money is driving Africa's cashless future. Harvard Business Review Publishing.

Bonface., R. M., \& Ambrose, J. (2015). Mobile Banking and Financial Performance of Commercial Banks in Kenya. International Journal of Finance and Current Business Studies, 4(12), 16-31.

Brigham, E. F., \& Gapenski, L. C. (1997). Financial Management: Theory and Practice. USA: The Dryden Press.

Capgemini. (2012). Trends in Retail Banking Channels: Improving Client Service and Operating Costs. Retrieved March 24, 2015 from http://www.capgemini.com/banking

Central Bank of Kenya. (2012). Annual Bank Supervision Annual Report. Government Printers, Nairobi Kenya.

Central Bank of Kenya. (2013). Annual Bank Supervision Annual Report. Government Printers, Nairobi Kenya.

Central Bank of Kenya. (2014). Monthly Economic Review March, 2014. Government Printers, Nairobi Kenya.

Central Bank of Kenya. (2015a). $3^{\text {rd }}$ Quarter Banking Sector Report, November 2015. Government Printers, Nairobi Kenya

Central Bank of Kenya. (2015b). Kenya Financial Sector Stability Report 2014. Government Printers, Nairobi Kenya.

CGAP, IFC. (2013). Financial Access 2012: Getting to a more Comprehensive Picture. Access to Finance Forum Reports by CGAP and Its Partners No. 6, June 2013.

CGAP. (2006). Use of Agents in Branchless banking for the poor: Risks, Rewards and Regulation. Washington. Focus Note no.38, DC: CGAP/World Bank.

CGAP. (2008). Banking through Network of Retail Agents. Washington, DC: CGAP/World Bank.

CGAP. (2009). Financial Access 2009: Measuring Access to Financial Services around the World. Washington, DC: CGAP/World Bank.

CGAP. (2011). Global Standard -Setting Bodies and Financial Inclusion for the Poor. Toward Proportionate Standards and Guidance. Washington D.C: CGAP/World Bank.

Creswell, J. (1994). Research Design; Qualitative and Quantitative Approaches. Thousand Oaks, CA, Sage.

Creswell, J. (2008). Educational research: Planning, conducting, and evaluating quantitative and qualitative research. New Jersey: Pearson: Merrill Prentice Hall.

Diamond, D. (1984). Financial Intermediation and Delegated Monitoring. Review of Economic Studies, 51, 393-414. https://doi.org/10.2307/2297430

European Investment Bank. (2013). Banking in sub-Saharan Africa, Challenges and Opportunities. EIB's Economics Department, 2013.

Faure, A. P. (2013). Banking: An Introduction (1st ed.). Quoin Institute (Pty) Limited, USA.

Flamini, C., Valentina, C., McDonald, G., \& Liliana, S. (2009). The Determinants of Commercial Bank Financial 
performance in Sub-Saharan Africa. IMF Working Paper. https://doi.org/10.5089/9781451871623.001

Frei, F. X., Harker, P. T., \& Hunter, L. W. (1998). Innovation in Retail Banking. The Wharton Financial institutions Centre Publication, University of Pennsylvania.

FSD Kenya. (2011). Annual Report 2011. Retrieved 27 $7^{\text {th }}$ June 2013 from http://fsdkenya.org/publications/index.php

FSD Kenya. (2012). Reviews, 2012. "Driving Change Through Technology: The PostBank example". Retrieved $27^{\text {th }}$ June 2013 from http://fsdkenya.org/publications/index.php

Gutierrez, E., \& Singh, S. (2013). What Regulatory Frameworks Are More Conducive to Mobile Banking? Empirical Evidence from Findex Data. The World Bank Policy Research Working Paper 6652, October 2013. https://doi.org/10.1596/1813-9450-6652

Ignacio, M. (2009). The Economics of Branchless Banking. Innovations Technology Governance Globalization, 4(2), 57-75. https://doi.org/10.1162/itgg.2009.4.2.57

Ignacio, M., \& Siedek, H. (2008). Banking through Networks of Retail Agents. CGAP Focus Note No. 47. Retrieved $20^{\text {th }}$ March 2014 from http://www.cgap.org/p/site/c/template.rc/1.9.3922

James, C. V. H., \& John, M. W. (2001). Fundamentals of Financial Management (11th ed.). Pearson Education, Inc, India.

Jamie, A. (2010). M-banking in developing markets: Competitive and regulatory implications. Info: The Journal of Policy, Regulation and Strategy for Telecommunications, 12(1), 18-25. https://doi.org/10.1108/14636691011015358

Joppe, M. (2000). The Research Process. Retrieved on 25th April 2015 from http://www.ryerson.ca./mjoppe/rp.htm

Kamau, A. W. (2011). Intermediation efficiency and productivity of the Banking sector in Kenya. Interdisciplinary Journal of Research in Business, 1(9), 12-26.

Kenya Bankers Association. (2012). Customer Assessment of Reputation of Bank Agents and Principal Bank and what informs the choice of the Bank. KBA Mama Ngina Street, Nairobi.

Kongiri, A. T. (2012). Effects of CAMEL variables on bank efficiency: A panel analysis of Kenyan Commercial Banks. Unpublished MBA Research project. University of Nairobi, 2012.

Mugo, H. W., Wanjau, K., \& Ayodo, E. M. (2012). An investigation into competitive intelligence practices and their effect on financial performance of firms in the banking industry: A case of Equity Bank. International Journal of Business and Public Management, 2(2), 61-71.

Mwangi, L. (2012). Agent Banking as a diversification Strategy by Commercial Banks in Kenya. University of Nairobi, Kenya.

Ndungu, C. G., \& Njeru, A. (2014). Assessment of Factors Influencing Adoption of Agency Banking in Kenya: The Case of Kajiado North Sub County. International Journal of Business and Commerce, 3(8), 91-111.

Odunga, R. M., Nyangweso, P. M., Carter, D. A., \& Mwarumba, M. (2013). Credit Risk, Capital Adequacy and Operating Efficiency of Commercial Banks in Kenya. International Journal of Business and Management, 2(9), 6-12.

Okiro, K., \& Ndungu, J. (2013). The impact of Mobile and Internet Banking on Performance of Financial Institutions in Kenya. European Scientific Journal, 9(13).

Ongore, V. O., \& Kusa, G. B. (2012). Determinants of Financial Performance of Commercial Banks in Kenya. International Journal of Economics and Financial Issues, 3(1), 237-252.

Rosen, T. V. (2013). Branchless Banking in Kenya: Does Mobile Banking and Agent Banking have the potential to lift the welfare of low - income individuals? Lund University.

Saunders, M., Lewis, P., \& Thornhill, A. (2003). Research Methods for Business Students (3rd ed). Harlow: Prentice Hall.

Siedek, H. (2007). “Banking Agents-Market Reach” PowerPoint presentation. Retrieved on 28th March 2014 from http://www.cgap.org/gm/document-1.9.2115/agents_marketreach.pdf

Siedek, H. (2008). Extending Financial Services with Banking Agents. Washington, D.C.: CGAP, April 2008.

Valentina, F., Calvin, M., \& Lillian, S. (2009). The Determinants of Commercial Bank Financial performance in 
Sub-Saharan Africa. IMF Working Paper. WP/09/15.

Vandesompele, J., De Preter, K., Pattyn, F., Poppe, B., Van Roy, N., De Paepe, A., \& Speleman, F. (2002). Accurate normalization of real-time quantitative RT-PCR data by geometric averaging of multiple internal control genes. Genome biology, 3(7), 34. https://doi.org/10.1186/gb-2002-3-7-research0034

Vutsengwa, R. M., \& Ngugi, K. (2013). An assessment of the challenges facing commercial banks in sustainability of branchless banking in Kenya: A case of commercial banks. International Journal of Social Sciences and Entrepreneurship, 1(2), 613-620.

World Bank. (2010). Banking Sector Stability, Efficiency, and Outreach in Kenya. The World Bank Group Development Research Group- Policy Research Working Paper 5442, October 2010.

World Bank. (2012). Financial Inclusion in Africa. An Overview. World Bank Policy Research Paper 6088 June 2012.

\section{Copyrights}

Copyright for this article is retained by the author(s), with first publication rights granted to the journal.

This is an open-access article distributed under the terms and conditions of the Creative Commons Attribution license (http://creativecommons.org/licenses/by/4.0/). 